\title{
O Relatório Meltzer de 2000 e a reforma do Banco Mundial e do FMI
}

The 2000 Meltzer Report and the World Bank and IMF reform

JOÃO MÁRCIO MENDES PEREIRA*

Rev. Bras. Polít. Int. 54 (2): 118-137 [2011]

Debe incluirse como parte del sistema estadounidense la red global de organizaciones especializadas, particularmente las instituciones financieras “internacionales". El Fondo Monetario Internacional (FMI) y el Banco Mundial se consideran representantes de los intereses "globales" y de circunscripción global. En realidad, empero, son instituciones fuertemente dominadas por los Estados Unidos y sus orígenes se remontan a iniciativas estadounidenses.

Zbigniew Brzezinski (1998, 36-37)

Los expertos del FMI y del Banco Mundial parecen tener todos los atributos de una autoridad internacional, pero no obstante abrigan ciertas dudas respecto al tipo de poder con el que cuentan. Dentro del ámbito de Washington, ellos ocupan una posición paradójica. Por una parte se encuentran cerca de los lugares en donde las decisiones cruciales son tomadas, pero, por otra, la dita proximidad sólo resalta su propia falta de autonomía en los juegos de poder sobre los que tienen un controle precario.

Yves Dezalay e Bryant Garth $(2005,137)$

\section{Introdução}

Desde meados dos anos 1990 a eclosão de crises financeiras alimenta o debate sobre a reforma das instituiçôes financeiras internacionais (IFIs) - em particular, do Banco Mundial e do Fundo Monetário Internacional (FMI). Em pauta estão desde a revisão da representação dos Estados nessas instituições até o papel que elas deveriam ou poderiam cumprir na economia mundial do início do século 21 , marcada por uma alta volatilidade e pela discrepância aguda entre a magnitude das massas de capital transacionadas diariamente nos mercados financeiros e o tamanho da carteira de empréstimos das instituições de Bretton Woods.

* Professor adjunto do curso de História e do Programa de Pós-Graduação em História da Universidade Federal Rural do Rio de Janeiro (UFRRJ) (joao_marcio1917@yahoo.com.br). 
Com a crise econômica deflagrada em 2008 nos Estados Unidos e logo disseminada para outras regiōes não foi diferente. Àquela altura, parte do establishment oficial e privado americano e diversos analistas da academia e da imprensa de negócios dos Estados Unidos afirmavam que o Banco Mundial e o FMI atravessavam a maior crise de relevância da sua história. A recessão das maiores economias do mundo (Estados Unidos, Japão e zona do euro), o avanço e a disseminação da crise e o retorno do nacionalismo econômico em alguns países, porém, obrigaram as grandes potências - a começar pelos Estados Unidos - a se mobilizarem. Rapidamente, o tema da irrelevância do Banco Mundial e do FMI foi posto de lado em nome da necessidade do seu fortalecimento como instrumentos de gestão da crise. Resultado: o FMI nunca emprestou tanto e tão rapidamente como na segunda metade de 2008, enquanto os compromissos financeiros do Banco Mundial saltaram de US\$24,7 bilhōes em 2008 para US\$ 58,7 bilhōes em 2010.

Nesse contexto, vale a pena revisitar um dos episódios relativos à reforma do FMI e do Banco Mundial mais contundentes da história: o trabalho da Comissão Consultiva sobre Instituições Financeiras Internacionais do Congresso americano entre 1998-2000 e seus desdobramentos imediatos.

\section{O Relatório Meltzer}

No calor da crise financeira que varreu grande parte da Ásia oriental, a controvérsia sobre o papel das IFIs ganhou nova dimensão. Em novembro de 1998, o Congresso americano aprovou a liberação de fundos adicionais ao FMI da ordem de US\$ 18 bilhões, com o objetivo de fazer frente à tormenta. Porém, a oposição conservadora exigiu a designação de uma Comissão Consultiva sobre Instituiçôes Financeiras Internacionais para analisar, em seis meses, sete instituiçôes importantes e recomendar mudanças. A presidência da comissão ficou a cargo do republicano Allan Meltzer e foi composta por outros 10 especialistas (5 indicados pelos republicanos e 5 pelos democratas) provenientes dos meios financeiro, político e acadêmico dos EUA, como mostra a Tabela 1. O trabalho centrou-se no FMI, no Banco Mundial ${ }^{1}$ e nos três bancos regionais de desenvolvimento - Banco Interamericano de Desenvolvimento (BID), Banco de Desenvolvimento Africano (BAfD) e Banco de Desenvolvimento Asiático (BAD) -, deixando em segundo

\footnotetext{
1 O Banco Mundial é constituído por duas organizaçôes: o Banco Internacional de Reconstrução e Desenvolvimento (Bird) e a Associação Internacional de Desenvolvimento (AID). O Bird foi criado em 1944 junto com o FMI na conferência de Bretton Woods, patrocinada pelos EUA, e começou a operar em 1946. Concede empréstimos a governos de países de renda média e a países de baixa renda solventes, captando recursos em mercados de capital e emprestando a seus clientes em condiçōes próximas às do mercado financeiro internacional (hard loans). Já a AID foi criada em 1960 para conceder empréstimos de longo prazo e com baixas taxas de juros (soft loans) a países pobres com pouca ou nenhuma capacidade de tomar emprestado nas condiçóes de mercado. A AID tem três fontes de financiamento: contribuiçōes do Bird, pagamento com juros dos empréstimos que realiza e, a mais importante, contribuiçōes voluntárias negociadas entre países doadores a cada três anos. Enquanto o Bird dá lucro e se baseia financeiramente no mercado, a AID depende das doaçôes de alguns Estados para sobreviver. Para mais informaçōes, vide Pereira (2010, cap. 1).
} 
plano a Organização Mundial do Comércio (OMC) e o Banco de Compensações Internacionais - Bank for International Settlements (BIS). A partir de dados fornecidos pelas próprias instituiçôes, especialmente pelos bancos, a comissão concluiu o relatório final em fevereiro de 2000. O impacto do Relatório Meltzer - como ficou conhecido - sobre as instituições gêmeas de Bretton Woods, em particular sobre o Banco Mundial, foi devastador.

Tabela 1. Membros da Comissão Meltzer.

\begin{tabular}{|c|c|c|}
\hline Nome & Filiação política & Atividade profissional \\
\hline Allan Meltzer & Republicano & $\begin{array}{l}\text { Professor na Carnegie Mellon University e no } \\
\text { American Enterprise Institute, membro do } \\
\text { conselho de assessores econômicos da presidência } \\
\text { em 1988-1989, entre outros postos. }\end{array}$ \\
\hline Charles Calomiris & Republicano & $\begin{array}{l}\text { Professor em Columbia e codiretor do projeto } \\
\text { sobre desregulação financeira do American } \\
\text { Enterprise Institute. }\end{array}$ \\
\hline Tom Campbell & Republicano & Professor em Stanford e congressista. \\
\hline Edwin Feulner & Republicano & $\begin{array}{l}\text { Presidente da Fundação Heritage e ex-presidente } \\
\text { da Sociedade Mont Pelerin. }\end{array}$ \\
\hline W. Lee Hoskins & Republicano & $\begin{array}{l}\text { Presidente e diretor-geral do Huntington National } \\
\text { Bank entre 1991-1997 e do Federal Reserve de } \\
\text { Cleveland entre 1980-1987. }\end{array}$ \\
\hline Manuel Johnson & Republicano & $\begin{array}{l}\text { Professor na George Mason University entre } \\
\text { 1977-1994, secretário assistente do Tesouro } \\
\text { entre 1982-1986, vice-diretor do Federal Reserve } \\
\text { entre 1986-1990 e sócio principal da firma de } \\
\text { consultoria Smick Medley. }\end{array}$ \\
\hline Richard Huber & Democrata & $\begin{array}{l}\text { Ex-diretor, presidente e gerente-geral da Aetna, } \\
\text { Inc., megacorporação do ramo de saúde. }\end{array}$ \\
\hline Jeffrey Sachs & Democrata & $\begin{array}{l}\text { Professor em Harvard e assessor econômico de } \\
\text { governos na América Latina, Europa oriental e } \\
\text { ex-URSS, Ásia e África. }\end{array}$ \\
\hline Fred Bergsten & Democrata & $\begin{array}{l}\text { Secretário assistente do Tesouro entre 1977-1981 } \\
\text { e diretor do Institute for International Economics } \\
\text { desde 1981, entre outros postos. }\end{array}$ \\
\hline Jerome Levinson & Democrata & $\begin{array}{l}\text { Diversos cargos na área de ajuda externa bilateral } \\
\text { desde a década de } 1960 .\end{array}$ \\
\hline $\begin{array}{l}\text { Esteban Edward } \\
\text { Torres }\end{array}$ & Democrata & $\begin{array}{l}\text { Assessor especial da presidência entre 1979-1981 } \\
\text { e congressista entre 1983-1999, entre outros } \\
\text { postos. }\end{array}$ \\
\hline
\end{tabular}


A Comissão aprovou uma breve resolução por unanimidade e o informe final por 8 votos contra 3. Votaram a favor todos os republicanos e parte dos democratas - Fred Bergsten, Jerome Levinson e Esteban E. Torres. A resolução afirmou dois pontos: primeiro, o FMI, o Banco Mundial e os três bancos regionais deveriam cancelar a dívida dos países pobres altamente endividados que implementassem "uma estratégia de desenvolvimento econômico e social eficaz, em conexão com o Banco Mundial e as instituições de desenvolvimento regional"; segundo, o FMI deveria concentrar a sua carteira na provisão de liquidez em curto prazo, abandonando a concessão de empréstimos de longo prazo para programas de redução da pobreza e outros fins (Meltzer et al. 2000, 18). Em outras palavras, recomendava-se, por um lado, o cancelamento da dívida multilateral dos países mais pobres à execução das reformas macroeconômicas e institucionais apregoadas pelas instituiçōes de Bretton Woods e sob a sua supervisão; por outro lado, pregava-se o enxugamento do papel do FMI à condição de "bombeiro" do sistema financeiro internacional, reduzindo-se a abrangência da sua atuação - ainda que, por outro viés, se reforçasse a importância do Fundo no âmbito da promoção de programas de ajustamento estrutural.

O Relatório Meltzer teceu críticas bastante duras às IFIs e propôs a reforma ampla de cada uma, sobretudo do Banco Mundial, bem como uma nova divisão de trabalho entre elas. A rigor, parte das críticas reiterou questionamentos já desferidos por think tanks liberal-conservadores como o Cato Institute e a Heritage Foundation (Eberstadt e Lewis 1995; Bandow e Vásquez 1994) e por organizações não governamentais ambientalistas e de defesa dos direitos humanos em campanhas como 50 Years is Enough (50 Anos Bastam) (Danaher 1994). Todavia, como um todo, o Relatório propiciou elementos novos ao debate sobre o presente e o futuro das organizações gêmeas de Bretton Woods.

O Relatório partiu de três ideias-chave. A primeira era a redução drástica da importância das IFIs como provedoras de fundos para mercados emergentes diante do agigantamento dos fundos provenientes dos mercados de capital, embora alguns países pobres continuassem altamente dependentes do dinheiro das IFIs. A segunda era a perda da importância política estratégica dos empréstimos multilaterais após o fim da Guerra Fria. A terceira, a reforma das IFIs como medida vital para a manutenção da "liderança" dos EUA no plano internacional.

Em linhas gerais, segundo o Relatório, os problemas mais importantes das IFIs seriam: a) a superposição considerável de ações entre o Banco Mundial e o FMI, e entre o primeiro e os demais bancos regionais de desenvolvimento; b) a amplitude excessiva do seu âmbito de atuação; c) a falta de transparência e responsabilização (accountability) das suas operações; d) a impossibilidade de evitar o aumento da frequência e da intensidade das crises financeiras internacionais; e) o confisco de recursos internacionais para cumprir objetivos definidos pelo governo dos EUA ou pelo Tesouro americano; f) a incapacidade de desenvolver programas regionais e globais bem-sucedidos para fazer frente a problemas transnacionais em áreas como 
meio ambiente e saúde pública, entre outras; g) o uso excessivo de empréstimos condicionados e a imposição de múltiplas condicionalidades; h) a incapacidade de fazer com que os tomadores de crédito cumprissem os compromissos acordados; i) a reticência em reduzir os empréstimos aos países que não cumpriam com suas obrigações (Meltzer et al. 2000, 31).

O Relatório criticou a atuação do FMI nas crises financeiras do México (1982 e 1994-1995), do leste da Ásia (1997-1998) e da Rússia (1998-1999), afirmando que a assistência prestada pelo Fundo não as preveniu nem as tratou do modo mais eficaz. Conclusão: "as intervenções do FMI (tanto a assistência estrutural a longo prazo como o controle das crises a curto prazo) não estão associadas, em geral, com nenhum benefício econômico claro para os países receptores" (ibid., 45). O Relatório reconheceu que "os governos do G7, particularmente o dos EUA, usam o FMI como um veículo para lograr fins políticos próprios”, e afirmou que a instrumentalização do Fundo pelo Poder Executivo "perturba o processo democrático dos países credores ao eludir a autoridade parlamentar sobre a ajuda externa ou a política exterior" (ibid.).

Como solução, o Relatório propôs a reestruturação do FMI como uma instituição mais enxuta voltada para três únicas funçōes, as quais, se levadas a cabo corretamente, "incrementariam a estabilidade global, melhorariam o funcionamento dos mercados e ajudariam os países a melhorar suas políticas monetárias e fiscais internas" (ibid., 47). A primeira função seria a de evitar crises financeiras e a sua propagação, provendo liquidez a economias emergentes solventes. Nesse sentido, o FMI passaria a atuar como "quase-emprestador de última instância", e não em primeira instância, a fim de - segundo o Relatório - minimizar o risco moral (moral hazard), isto é, a certeza de que, na hora de o mercado cobrar o seu preço, a instituição e o Estado salvarão os grandes investidores de um modo ou de outro. Para terem acesso à assistência financeira do FMI, os países teriam de cumprir um conjunto de condiçóes consideradas relativamente fáceis de monitorar e de pôr em prática - como a abertura do mercado doméstico aos bancos estrangeiros, ajuste fiscal rigoroso e controle inflacionário -, e não mais um rol extenso de mudanças estruturais, institucionais e financeiras, como vinha ocorrendo. Os países préqualificados pelo FMI teriam condiçóes melhores de obter acesso a empréstimos privados em termos mais favoráveis. Os países não qualificados só receberiam assistência financeira se implementassem reformas estruturais, cuja supervisão ficaria a cargo do Banco Mundial, dos bancos regionais e do próprio "mercado". A segunda função do FMI seria, precisamente, a de recolher, publicar e disseminar informação financeira e econômica sobre os países-membros, a fim de orientar os investidores privados sobre o seu desempenho econômico. Por fim, a terceira função seria a de "proporcionar assessoramento (porém não impor condiçōes) com relação à política econômica” dos países-membros (ibid., 48).

No que diz respeito ao Banco Mundial e aos três bancos multilaterais regionais, o Relatório constatou altos custos e baixa efetividade na redução da 
pobreza e no fomento às reformas institucionais. As causas de tal desempenho, segundo o informe, radicavam no fato de que: a) a maior parte dos recursos do Banco fluía para alguns poucos países que já tinham acesso a capitais privados; b) a quantidade de fundos que os bancos multilaterais proviam aos seus principais tomadores de empréstimos era ínfima, quando comparada aos recursos obtidos nos mercados financeiros; c) a garantia dada pelo governo receptor - requisito para todos os empréstimos do Banco - eliminava na prática qualquer conexão entre o fracasso do projeto e o risco de perda do Banco; d) a fungibilidade do dinheiro dificultava ou mesmo impossibilitava o monitoramento do uso adequado dos recursos emprestados; e) os Estados não implementavam reformas impostas por terceiros - no caso, por organismos multilaterais; f) projetos de desenvolvimento só tinham êxito se o país receptor tivesse interesse significativo no projeto e canalizasse esforços para viabilizá-lo (ibid., 29-30).

A partir de dados fornecidos pelo próprio Banco Mundial, o relatório mostrou que, entre 1993 e 1999, 70\% dos empréstimos do Banco Mundial - cerca de US\$ 13 bilhões - haviam sido destinados a apenas 11 países, todos com acesso amplo aos mercados de capitais. Tais cifras serviam para demonstrar, segundo o Relatório, a contradição entre o discurso em prol da redução da pobreza absoluta defendido pela instituição e a destinação efetiva da sua carteira. Por outro lado, o fato de que a soma emprestada aos 11 maiores tomadores representasse somente o equivalente a 1,4\% dos US $\$ 880$ bilhões providos por fontes privadas foi tomado como ilustração inapelável da pouca relevância do Banco como emprestador (ibid., 63). $\mathrm{O}$ informe não poupou palavras para diagnosticar a mudança radical do contexto internacional e a necessidade de readequação imediata do Banco Mundial e dos três bancos regionais:

Com o fim da guerra fria, os empréstimos como um movimento estratégico saíram de moda. A necessidade de comprometer grandes quantidades de capitais para a contenção terminou. Uma nova geração de líderes nos setores público e privado nas naçôes em desenvolvimento, educados nas universidades do Ocidente, converteram-se em sofisticados criadores de políticas (...). Os países abriram seus mercados; o comércio internacional floresceu e o capital humano, tecnológico e financeiro se movia mais facilmente. O que é mais importante, a explosão dos mercados financeiros, tanto em alcance como em desejo de assumir riscos, desafiou a vantagem comparativa dos Bancos [multilaterais] na transferência de recursos. (...). Os Bancos devem aceitar que não são mais uma fonte significativa de fundos para o mundo emergente, e que não podem prover mais do que uma pequena fração do que os mercados oferecem (ibid., 60).

Além de mostrar que a destinação dos recursos do Banco Mundial não visava aos países mais pobres, o Relatório apontou que a qualidade técnica dos projetos e programas financiados - avaliada segundo a relação entre objetivos e resultados - havia sido muito baixa durante o período 1990-1999, segundo os critérios do 
próprio Banco. Levando em conta o desempenho da instituição na África, no sul e no leste da Ásia e na América Latina, chegou-se à conclusão de que, como médias gerais, $47 \%$ dos empréstimos para ajustamento (estrutural e setorial) e $59 \%$ dos empréstimos para projetos fracassaram em obter resultados satisfatórios em longo prazo (ibid., 75). No continente africano - justamente onde o Banco deveria, em tese, mostrar a sua vantagem comparativa na redução da pobreza -, o percentual de fracasso chegou a $73 \%$.

O Relatório destacou, ainda, a superposição considerável de empréstimos do Banco Mundial e dos bancos regionais. A Tabela 2 ilustra essa superposição, particularmente alta em casos como Coreia, Indonésia e China na Ásia, Argentina, Brasil e México na América Latina e Marrocos, Argélia e Tunísia na África. Tal situação resultaria na perda de eficiência no uso de recursos e numa competição desnecessária por clientes e projetos (ibid., 65).

Tabela 2. Superposição dos empréstimos dos bancos regionais de desenvolvimento e do Banco Mundial (em milhões de dólares) - 1996-1998.

\begin{tabular}{lcccc}
\hline \multicolumn{5}{c}{ Ásia } \\
\hline & $\begin{array}{c}\text { BAD } \\
\text { Soma }\end{array}$ & Percentual na região & $\begin{array}{c}\text { Bird } \\
\text { Soma }\end{array}$ & Percentual na região \\
\hline Coreia & 4.015 & 24,6 & 7.048 & 27,7 \\
Indonésia & 3.767 & 23,1 & 4.223 & 16,6 \\
China & 2.920 & 17,9 & 6.487 & 25,5 \\
Índia & 1.576 & 9,6 & 2.095 & 8,2 \\
Tailândia & 1.510 & 9,2 & 2.068 & 8,1 \\
Filipinas & 1.419 & 8,7 & 1.141 & 4,5 \\
Total & 15.207 & 93,1 & 23.062 & 90,7 \\
\hline & & América Latina & & \\
\hline & BID & Percentual na região & Bird & Porcentual na região \\
\hline Argentina & 5.785 & 28,9 & 6.038 & 35,0 \\
Brasil & 4.642 & 23,2 & 4.296 & 24,9 \\
México & 1.829 & 9,1 & 3.677 & 21,3 \\
Peru & 1.493 & 7,4 & 1.080 & 6,3 \\
Venezuela & 1.030 & 5,1 & 122 & 0,7 \\
Uruguai & 882 & 4,4 & 269 & 1,6 \\
Colômbia & 768 & 3,8 & 302 & 1,8 \\
Total & 16.429 & 81,0 & 15.784 & 91,5 \\
\hline & & &
\end{tabular}




\begin{tabular}{lrrrr}
\hline \multicolumn{5}{c}{ África } \\
& $\begin{array}{l}\text { BAfD } \\
\text { Soma }\end{array}$ & Percentual na região & $\begin{array}{c}\text { Bird } \\
\text { Soma }\end{array}$ & Percentual na região \\
\hline Marrocos & 611 & 30,4 & 748 & 35,2 \\
Argélia & 580 & 28,9 & 239 & 11,2 \\
Tunísia & 414 & 20,6 & 658 & 30,9 \\
África do Sul & 154 & 7,7 & 46 & 2,2 \\
Total & 1.759 & 87,6 & 1.691 & 79,5 \\
\hline
\end{tabular}

Fonte: Meltzer $(2000,65)$.

Para modificar tal quadro, o Relatório propôs uma reforma ampla do Banco Mundial, dos bancos regionais e da divisão de trabalho entre eles. Em relação ao Banco Mundial, recomendou-se a redução significativa do seu papel de emprestador internacional. Todos os seus programas nacionais e regionais na América Latina e na Ásia passariam para os respectivos bancos regionais. Na África, o Banco permaneceria como a principal fonte multilateral de crédito, até que o BAfD tivesse condiçóes operacionais de assumir esse papel. Uma parte do seu capital passaria aos bancos regionais e a outra seria reduzida de acordo com a diminuição da sua carteira de empréstimos. Seu nome mudaria para Agência de Desenvolvimento Mundial e a sua atuação junto ao setor privado limitar-se-ia à provisão de assistência técnica e à disseminação de boas práticas. Empréstimos seriam cancelados. Mudanças na mesma direção ocorreriam nos bancos regionais, de tal maneira que, no conjunto, os mesmos concentrariam a sua atuação apenas nos 80 ou 90 países mais pobres, sem acesso aos mercados de capitais. Embora o Relatório admitisse que o desvio de recursos do Banco Mundial e dos demais bancos multilaterais para o socorro às crises financeiras tenha sido um meio pelo qual os maiores acionistas - com destaque para os EUA - executaram suas políticas internacionais sem se submeter ao processo orçamentário e legislativo, propôs-se que esse papel deveria caber, dali em diante, apenas ao FMI.

Segundo o Relatório, o Banco tinha crescido tanto e ocupava-se de tantas áreas que teria perdido eficiência no gasto dos recursos e eficácia nos resultados, razão pela qual seria preciso reduzir com urgência o seu tamanho e o seu âmbito de atuação. Ou seja, o Relatório criticava o Banco por fazer coisas demais e mal e propunha que o mesmo fizesse poucas coisas e bem; ironicamente, a mesma crítica que o Banco Mundial fazia genericamente ao Estado em inúmeras publicações (Banco Mundial 1991, 1996, 1996a, 1997; Burki e Perry 1998). Uma vez reformado, ele se concentraria em apenas duas funções. A primeira seria a produção de bens públicos globais, como "tratamentos melhorados para enfermidades tropicais e a AIDS, uma proteção racional dos recursos ambientais, sistemas de infraestrutura entre países, o desenvolvimento de tecnologia para a agricultura 
tropical e a criação de melhores práticas gerenciais e regulatórias" (ibid., 84). A segunda, mais estratégica, seria o fornecimento de assistência técnica a governos e bancos regionais direcionada à criação de sistemas legais que apoiassem direitos de propriedade claramente definidos, regimes fiscais e administrações públicas transparentes, políticas que promovessem o "livre fluxo de bens e capital ao longo prazo" e "normas de governança corporativas" (ibid., 85). Curiosamente, a educação não foi mencionada.

Em outras palavras, o novo Banco Mundial deixaria de atuar como prestamista e reforçaria o seu papel político e intelectual como promotor das reformas institucionais necessárias à realização da liberalização econômica. Nos países com acesso ao mercado de capitais, a carteira dos bancos passaria ao setor privado, desde que os Estados receptores dessem as mesmas garantias que davam aos bancos. De acordo com o Relatório, mesmo projetos comumente não financiados pelos mercados de capitais (como nas áreas de infraestrutura, desenvolvimento rural, etc.) estariam agora na sua órbita de valorização, uma vez isentos de riscos pelo Estado. Literalmente: "O setor privado está preparado para financiar projetos socialmente desejáveis com um fluxo de caixa limitado, se o governo garante pagar a dívida, como o faz quando os países pedem empréstimos dos bancos de desenvolvimento" (ibid., 61).

Já nos 1980 ou 1990, países tidos como "verdadeiramente pobres" (isto é, sem acesso aos mercados de capitais), o Banco Mundial e os bancos regionais continuariam financiando o aliviamento da pobreza focado na provisão de recursos para projetos de saúde pública, educação primária e infraestrutura física, porém eis a grande novidade - não mais por meio de empréstimos e sim de subvenções pagas diretamente aos projetos, com base no seu desempenho. As subvenções seriam outorgadas por licitações competitivas, cobririam de $10 \%$ a $90 \%$ dos custos dos projetos (dependendo do acesso aos mercados de capitais e da renda per capita) e seriam pagas diretamente aos provedores dos serviços (fossem eles nacionais ou estrangeiros), e não aos governos. Caberia ao Estado, mediante a assistência técnica dos bancos multilaterais, cobrir o restante dos custos dos projetos e atenuar/responder por eventuais riscos políticos (descumprimento de contratos, adulteração das regras do jogo, etc.). Os provedores poderiam ser organizações não governamentais (ONGs), empresas privadas ou agências públicas. A quantidade e a qualidade do desempenho seriam fiscalizadas por auditores externos (firmas especializadas). Tal enfoque situaria a ajuda externa no plano visível do mercado não apenas por rebaixar custos, mas por fixar metas e garantir a destinação correta dos fundos. Tal enfoque de aliviamento da pobreza estaria aberto também a doadores bilaterais. $\mathrm{O}$ esquema funcionaria da seguinte maneira:

Um país com renda de US\$ 1.000 per capita que se qualifica para uma subvenção de $70 \%$ decide que a vacinação de suas crianças contra o sarampo é uma meta desejável. Se a agência de desenvolvimento [isto é, o Banco 
Mundial ou um dos bancos regionais] confirma essa necessidade, o governo solicitaria ofertas competitivas de provedores do setor privado, organizações não governamentais, tais como instituiçôes de caridade, e entidades do setor público ou o Ministério da Saúde. Supondo que a oferta qualificada mais baixa fosse de US\$ 5 por criança vacinada, a agência de desenvolvimento acordaria pagar US\$ 3,5 (70\%) por cada vacina, diretamente ao provedor. O governo seria responsável pelo US\$ 1,5 restante da tarifa (30\%). Os pagamentos seriam feitos somente após a certificação de um agente independente. (Meltzer et al. 2000, 81).

De acordo com o Relatório, um sistema desse tipo teria uma dupla vantagem de manter os preços relativos dos insumos necessários à prestação do serviço e condicionar os pagamentos aos resultados. Para o provedor - especializado naquela atividade - haveria a certeza de lucro. A corrupção seria desestimulada, pois os pagamentos seriam efetuados diretamente aos provedores e teriam como base critérios de mercado. O mesmo sistema teria "o potencial de se estender além dos projetos nacionais, para programas regionais, onde a cooperação entre os governos participantes daria escala maior às economias" (ibid., 81).

Além desse novo modelo de assistência externa para o aliviamento da pobreza, o Relatório (ibid., 82-83) propôs também que o Banco Mundial e os bancos regionais concedessem empréstimos, com percentuais variáveis de subsídio sobre os juros, aos países mais pobres, com o objetivo de fomentar a realização de reformas institucionais ou apoiar a sua sustentação. O desempenho do programa de reformas seria avaliado por auditores independentes, e quanto mais eficiente fosse a sua implementação, mais favoráveis seriam as condições de pagamento dos empréstimos.

Uma das condiçóes que permitiria aos EUA insistir em um novo modelo de assistência externa condicionado estritamente ao desempenho e aos resultados seria, segundo o Relatório, o fim da Guerra Fria. Desde 1989, não haveria mais "qualquer razão fundamental para assistir a regimes corruptos e instáveis que tiveram alguma vez importância estratégica" (ibid., 57). Daí a necessidade de reforma das IFIs "para assegurar que cada dólar (...) leve consigo o incentivo de estimular o desempenho e alcançar resultados que possam ser monitorados" (ibid., 58).

A reforma das IFIs na direção proposta pelo Relatório serviria à manutenção da "liderança" dos EUA no plano internacional e ao avanço das reformas estruturais econômicas e institucionais, os quais, por sua vez, demandariam o aumento da influência americana sobre as IFIs. Literalmente:

O interesse dos EUA não é inteiramente comercial, financeiro ou mercantil. Com a ajuda de outras economias de mercado democráticas, somos os líderes em disseminar a democracia, o Estado de direito e a estabilidade econômica. Os esforços dos EUA para reestruturar as instituições financeiras internacionais deveriam continuar essa tradição de liderança, fomentando acordos apropriados 
para o novo ambiente que esses esforços criarão. As reformas são necessárias para permitir que as instituiçôes financeiras internacionais tenham um papel importante (...) durante os próximos 50 anos (Meltzer et al. 2000, 33).

Do ponto de vista político, as propostas contidas no Relatório Meltzer orientaram-se para: a) a potencialização da liberalização econômica internacional; b) a afirmação da primazia americana na condução da reforma das instituiçôes de Bretton Woods; c) o esvaziamento do papel financeiro dos bancos multilaterais de desenvolvimento (BMDs) em favor do financiamento privado em países de renda média; d) o condicionamento da anulação total ou parcial da dívida dos países mais pobres com as IFIs à execução das reformas econômicas liberais; e) a constituição de uma política de ajuda externa (multilateral e bilateral) aos países mais pobres baseada em subvençôes diretas a prestadores de serviços condicionadas à mercantilização plena dos serviços públicos, mensurada segundo critérios de resultado tangíveis.

\section{A minoria derrotada dentro da Comissão}

Embora concordassem com a necessidade de reforma das IFIs, os três membros da Comissão contrários ao texto final do Relatório consideraram suas proposições "falhas" e "totalmente carentes de respaldo", advertindo que, se adotadas, aumentariam o "risco de uma instabilidade global" e afetariam negativamente os "interesses dos EUA" (Meltzer et al. 2000, 103). Para eles, o Relatório apresentava uma visão enganosa do impacto econômico e social da ação das IFIs, uma vez que não reconhecia o papel que haviam desempenhado na promoção do crescimento econômico, na redução da pobreza e na manutenção da hegemonia americana. Nas suas palavras: "O resultado final da 'era das IFIs', apesar das imperfeições óbvias, é um êxito indubitável, de proporções históricas, em termos tanto econômicos como sociais. Os Estados Unidos se beneficiaram enormemente como resultado dela" (ibid., 103).

Em relação ao FMI, afirmaram que a proposta de limitar o papel do FMI ao apoio a países pré-qualificados à sua assistência simplesmente minaria a sua capacidade de prevenir e responder a uma crise financeira internacional. Sem a autorização para negociar reformas de políticas, o FMI não poderia fazer com que o socorro financeiro servisse de veículo para a saída da crise. Por outro lado, limitar a atuação do Fundo a um rol de critérios pré-qualificadores esvaziaria a importância política dos países que o apoiam, o que fomentaria a desordem econômica global (ibid., 104-6).

Em relação ao Banco Mundial, os três membros da Comissão declararam que, se aplicadas, as propostas do Relatório: a) limitariam os fundos direcionados aos países mais pobres; b) castigariam os países pobres que obtinham acesso aos 
mercados de capitais ao negar-lhes empréstimos; c) tornaria os empréstimos multilaterais aos países mais pobres dependentes da "boa vontade" dos países doadores, uma vez que os créditos da Associação Internacional de Desenvolvimento (AID) eram financiados por repasses do Bird, os quais, em larga medida, dependiam dos países de renda média e de grandes projetos de infraestrutura; d) deixaria os países de renda média totalmente dependentes da volatilidade dos mercados de capitais; e) esvaziaria o papel desempenhado pelo Banco no fortalecimento de coalizões domésticas comprometidas com as reformas liberais (ibid., 106-8).

\section{A resposta do Tesouro}

Quatro meses depois da conclusão do Relatório Meltzer, já no final do mandato do presidente Bill Clinton, saiu a resposta oficial do Tesouro. Destacando os pontos de concordância e discordância, a resposta reafirmou a importância estratégica das IFIs para os interesses econômicos e políticos dos EUA:

As IFIs estão entre os mais efetivos e eficientes meios disponíveis para avançar as prioridades da política norte-americana pelo mundo. Desde o seu nascimento, elas são centrais para tratar dos principais desafios econômicos e do desenvolvimento do nosso tempo. Elas promovem crescimento, estabilidade, mercados abertos e instituições democráticas, resultando em mais exportaçôes e empregos nos Estados Unidos, enquanto avançam nossos valores fundamentais por todo o mundo (U.S. Department of Treasury 2000, 2).

Como produto do que chamou de consenso bipartidário sobre a política americana para as IFIs, o Tesouro arrolou sete pontos de concordância com o Relatório Meltzer: a) a necessidade de maior transparência das instituições; b) a criação de novos mecanismos para incentivar os países a reduzirem a sua vulnerabilidade a crises financeiras, como a linha de crédito contingente do FMI, condicionada à realização ex-ante de reformas estruturais; c) um novo foco dentro das IFIs sobre a importância de sistemas financeiros fortes e abertos, administração da dívida e regimes cambiais mais flexíveis; d) a revisão do enfoque de empréstimos das IFIs para os países mais pobres, centrada numa maior seletividade e com foco ainda mais direcionado ao crescimento econômico, ao combate à corrupção e à redução da pobreza, sobretudo por meio de investimentos em saúde e educação básicas; e) um aumento do cancelamento da dívida e da ajuda financeira dirigida aos países mais pobres; f) o protagonismo dos bancos multilaterais de desenvolvimento junto à comunidade internacional na provisão de bens públicos globais, como a promoção do desenvolvimento sustentável, o combate a doenças infecciosas e a adoção de boas práticas de desenvolvimento; g) maior clareza na distinção dos respectivos papéis desempenhados pelos bancos multilaterais de desenvolvimento e pelo FMI (U.S. Department of Treasury 2000, 3-4). 
Após elencar os pontos de concordância, o Tesouro passou aos pontos de discordância. Na visão do governo Clinton, como um todo as propostas de reforma das IFIs apresentadas pelo Relatório Meltzer prejudicariam a funcionalidade delas para a defesa da economia e dos interesses estratégicos americanos. Literalmente:

O teste crítico na avaliação da conveniência de propostas alternativas de reforma deveria ser uma avaliação sobre se elas fortaleceriam ou enfraqueceriam a capacidade das instituiçôes para tratar dos desafios econômicos que são críticos para os interesses dos Estados Unidos. Na nossa visão, as recomendaçôes centrais da maioria, tomadas como um todo, prejudicariam substancialmente os interesses estratégicos econômicos e nacionais dos Estados Unidos, por reduzir dramaticamente a capacidade do FMI e dos BMDs de responder a crises financeiras e privá-los de instrumentos efetivos para promover a estabilidade financeira internacional e a reforma econômica orientada ao mercado e ao desenvolvimento. (...) Especificamente, se as propostas da maioria da Comissão estivessem em seu lugar em 1997 e 1998, nem o FMI nem o Banco Mundial seriam capazes de responder à crise financeira severa que se espalhou pelos mercados emergentes durante aquele período. Como resultado, a crise seria mais profunda e mais prolongada, com maior devastação sobre as economias afetadas e consequências potencialmente muito mais severas para produtores rurais, trabalhadores e homens de negócio norte-americanos (ibid., 5).

Referindo-se ao Banco Mundial e aos demais BMDs, a posição do Tesouro foi igualmente clara:

Se as recomendações da Comissão fossem aplicadas tal como escritas, países tão diversos como Brasil, Indonésia, Turquia e África do Sul - onde interesses estratégicos e econômicos importantes e de longo prazo dos Estados Unidos estão claramente em jogo - teriam acesso negado à assistência dos BMDs. Se essas recomendaçôes fossem aplicadas hoje, o Banco Mundial e os bancos regionais de desenvolvimento seriam efetivamente excluídos de empréstimos de todo tipo, em qualquer circunstância. Esses países atualmente absorvem inteiramente um terço das exportaçôes norte-americanas, uma porção que cresceu consideravelmente durante a década passada. Além disso, eles são o lar de uma parte substancial dos pobres do mundo (ibid., 27).

Segundo o Tesouro, se as propostas de reforma contidas no Relatório Meltzer estivessem em vigor no início dos anos 1990, teriam excluído os BMDs do apoio à liberalização econômica nas sociedades do leste da Ásia e na América Latina, precisamente "em um período de oportunidades históricas para a reforma construtiva” (ibid., 5). Sem a ação dos BMDs, o apoio para as políticas de desregulação financeira, liberalização comercial, privatização, reforma agrícola e outras em economias que, naquele momento, eram sócias comerciais cada vez mais importantes dos EUA teria sido, enfim, muitíssimo menor. 
Para o Tesouro, ainda, o esvaziamento do papel financeiro do Banco Mundial proposto pelo Relatório Meltzer oneraria os EUA ao obrigar o país a aumentar os gastos com a assistência bilateral ao desenvolvimento, contrariando a queda dessa modalidade ao longo dos anos 1990 (ibid., 5).

$\mathrm{Na}$ visão do Tesouro (ibid., 7-8), as propostas do Relatório Meltzer para o Banco Mundial e os bancos regionais seriam desastrosas para o avanço internacional da liberalização econômica por várias razões. Em primeiro lugar, porque eliminariam a capacidade dessas instituições de impulsionar a reestruturação econômica em países que contavam com grandes mercados nacionais, uma agenda extensa de reformas ainda pendentes e, em muitos casos, acesso frágil e limitado aos mercados privados de capital. Em segundo lugar, porque limitariam enormemente a capacidade dos BMDs de promover a empresa privada, a privatização de empresas públicas e o desenvolvimento de mercados domésticos de capitais. Em terceiro lugar, porque reduziria o âmbito de ação do Banco Mundial, precisamente a instituição "mais forte, mais experiente e mais competente" entre todos os BMDs (ibid., 8). Em quarto, porque a retirada dos BMDs do papel de fornecedores de empréstimos de emergência para países em crise financeira não poderia ser inteiramente suprida pelo FMI. Em quinto, porque o sistema de subvenções diretas a prestadores de serviço simplesmente não funcionaria. Haveria falta de recursos para a assistência financeira multilateral, em função do fim da alavancagem financeira fornecida pelos empréstimos convencionais dos BMDs - cada US\$ 1 aportado pelos EUA entre 1995 e 1999 havia gerado US\$ 60 de assistência ao desenvolvimento - e dos recursos advindos dos pagamentos de créditos concessionários. Além disso, a subvenção direta não seria um instrumento financeiro efetivo quando comparada aos empréstimos convencionais, pelo fato de não fomentar melhorias no enfoque geral de políticas e nas instituições públicas domésticas.

O Tesouro também expôs a agenda de reformas do governo Clinton para os BMDs. Seis áreas deveriam ser revistas (ibid., 12-14). Em primeiro lugar, a concessão de empréstimos e créditos dos BMDs deveria seguir metas claras e mensuráveis de performance dos clientes, excluindo do acesso ao financiamento aqueles que não apresentassem resultados tangíveis no avanço da liberalização econômica e das reformas institucionais. Em segundo lugar, os BMDs deveriam focalizar as suas carteiras de empréstimos para a redução da pobreza, priorizando os investimentos em saúde primária, educação básica e água potável. No âmbito da assistência técnica, os bancos deveriam orientar os Estados a como remodelar o gasto público de modo a priorizar aquelas áreas. Em terceiro lugar, os BMDs deveriam estabelecer uma abordagem mais seletiva que facilitasse a graduação dos clientes, de modo que os empréstimos declinassem à medida que eles expandissem a sua capacidade para atrair financiamento privado. Não deveriam ser cogitados novos aumentos do capital geral dos bancos para hard loans, apenas para soft loans. Em quarto lugar, os BMDs precisariam dar às suas operaçôes um alto grau de transparência. Em quinto lugar, o Banco Mundial e os demais bancos 
multilaterais deveriam fomentar e coordenar esforços internacionais para a provisão de bens públicos globais no âmbito da saúde pública e da gestão ambiental. Por fim, a relação entre os BMDs e o FMI deveria ser mais seletiva, a fim de eliminar sobreposiçōes e inconsistências.

As propostas do Relatório Meltzer para o FMI também foram rejeitadas pelo Tesouro. Primeiro, porque limitaria os empréstimos do FMI apenas a países pré-qualificados, deixando de fora um número potencialmente grande de clientes. Segundo, porque retiraria do FMI a aplicação de condicionalidades mais duras e amplas, consideradas vitais para a restauração da confiança dos investidores privados e a retomada do crescimento econômico. Terceiro, porque eliminaria a capacidade do FMI de fornecer créditos mais brandos aos países pobres, enfraquecendo tanto a pressão pela adoção de políticas econômicas liberais como a efetividade da ajuda externa ao desenvolvimento (ibid., 6-7).

As propostas do Tesouro para a reforma do FMI abarcaram cinco pontos. Primeiro, que o Fundo priorizasse o fornecimento de um fluxo permanente de informações dos governos para os mercados. Segundo, que esse trabalho de vigilância se concentrasse nos pontos mais suscetíveis à maior vulnerabilidade financeira, como taxas de câmbio e indicadores de liquidez. Terceiro, que o FMI atuasse principalmente na prevenção do contágio nos mercados emergentes e jogasse um papel mais ativo na provisão de um enfoque macroeconômico - em conjunto com os programas de redução da pobreza do Banco Mundial - nos países mais pobres. Quarto, que o Fundo enfatizasse as soluçōes das crises financeiras baseadas no mercado, isto é, na catalisação de financiamento privado em termos apropriados, a fim de reduzir o risco moral. Quinto, que o FMI se modernizasse como instituição, o que passaria pela criação de um departamento de avaliação de operações (como já existia no Banco Mundial) e de um grupo formal, constituído por financistas, para "aprofundar o entendimento do Fundo sobre as tendências do mercado global" (ibid., 12). A revisão da distribuição do poder de voto dos Estados-membros mereceu uma única linha em todo o documento.

O Tesouro foi terminantemente contra a proposta de perdão da dívida multilateral dos países mais pobres altamente endividados apresentada pelo Relatório Meltzer. Além de estimular o risco moral, tal medida minaria, segundo o Tesouro, uma fonte cada vez mais importante de financiamento da AID: o pagamento dos débitos pelos mutuários. Com isso, haveria menos fundos disponíveis para países elegíveis aos créditos da AID. Em lugar do cancelamento, que custaria ao Banco Mundial cerca de US\$20,3 bilhões, o Tesouro propôs um plano de redução da dívida dos países pobres que custaria ao Banco apenas US\$ 6,3 bilhōes (ibid., 39-41).

\section{Governo Bush e incorporação seletiva das propostas do Relatório Meltzer}

Com a posse de George W. Bush em janeiro de 2001 e a conformação de uma maioria parlamentar republicana, não houve mais ataques daquela virulência 
contra as IFIs por parte do Congresso. Tal como ocorrera com os governos Ronald Reagan e George H. W. Bush, a passagem da direita republicana do Congresso para o Executivo tende a moderar o seu discurso - recorrente desde o final dos anos 1970 - acerca do ônus político e financeiro dos organismos multilaterais para os EUA, a partir do reconhecimento de que tais organizações são, na verdade, instrumentos úteis demais para a defesa de interesses americanos de longo prazo para serem fragilizadas ou mesmo desmanteladas (Babb 2009, 18; Pereira 2010, 242-74).

Inicialmente, o novo governo tomou as IFIs como veículos de promoção da liberalização econômica, seguindo a linha dos seus antecessores. Depois de 11 de setembro de 2001, porém, a segurança e o humanitarismo foram postos no centro da política externa americana para as IFIs, traduzindo-se numa colagem entre pobreza e instabilidade política global. Os objetivos econômicos não foram abandonados, mas enquadrados como meios para fins geopolíticos. Ou seja, depois do 11 de setembro, o governo Bush pautou o interesse americano nas IFIs com um novo amálgama de temas que fundia o liberalismo do Consenso de Washington, o neoconservadorismo religioso sob a forma da teologia da ajuda aos pobres e a guerra contra o terrorismo (Babb 2009, 214-15). Além disso, o Banco Mundial foi alçado à linha de frente das operações de "reconstrução" do Afeganistão e do Iraque por meio de empréstimos - que se materializavam em contratos altamente lucrativos para firmas americanas e europeias - e, sobretudo, assessoramento técnico para a reestruturação do Estado e a reescrita dos marcos constitucionais fundamentais.

Ligada à anterior, outra prioridade cara à política externa dos EUA (e do Reino Unido) assumida pelo Banco Mundial se traduziu no aumento da sua atuação nos chamados "Estados frágeis", caracterizados por alta instabilidade política, conflitos internos ou transfronteiriços graves e paralisação ou colapso da autoridade pública e do sistema de tomada de decisōes. O tema remete à literatura sobre Estados "fracassados" ou "falidos" (failed states), em voga no mainstream anglo-americano (Cooper 2003; Mallaby 2004; Fukuyama 2005). Nesse âmbito, o Banco criou em 2001 um Fundo Fiduciário para financiar operaçōes em países africanos. O Banco também passou a participar da coordenação de diversas iniciativas bilaterais - com a United States Agency for International Development (USAID) e o Department for International Development do Reino Unido - e multilaterais - com o Grupo de Aprendizagem e Assessoria da Organização para a Cooperação e Desenvolvimento Econômico (OCDE), a Organização das Nações Unidas (ONU) e a União Europeia.

A vitória de Bush criou uma nova oportunidade para a aplicação seletiva de ideias apresentadas no Relatório Meltzer e algumas delas orientaram a atuação da Conta do Desafio do Milênio (Millennium Challenge Account), a mais importante iniciativa de ajuda externa bilateral desenvolvida pelo governo republicano (Lancaster 2007). Com relação às IFIs, uma das ideias mais importantes empurradas pelos EUA foi a conversão de empréstimos em subvenções. A proposta, apresentada 
no encontro do G8 em 2001, sugeria que a metade dos recursos da AID no período 2003-2005 fosse gasta sob a forma de subvenções. Outros doadores, particularmente os europeus, foram contra e argumentaram que um componente de $10 \%$ de subvenção seria mais plausível, uma vez que parte dos recursos da AID advém do pagamento dos créditos acrescidos de juros, de modo que um percentual elevado de subvenções minaria em médio prazo a sua capacidade financeira, se não houvesse uma compensação por parte dos Estados doadores. Em maio de 2002, os EUA propuseram um grau de subvenção de $22 \%$. Em junho, o G7 anunciou um acordo de que entre $18 \%$ e $21 \%$ dos desembolsos da AID seriam sob a forma de subvençōes. Para a reposição de fundos seguinte (2006-2008), os EUA asseguraram um aumento da subvenção para 31\% dos desembolsos (Babb 2009, 223-24).

Mas a proposta mais polêmica, levada adiante no calor da disputa eleitoral de 2004, foi a de cancelamento total da dívida multilateral dos países pobres altamente endividados, a maior parte dos quais na África, cujo custo recairia integralmente sobre as IFIs. Essa proposta se chocava com a proposta britânica, que advogava um cancelamento mais moderado que oneraria o mínimo possível as IFIs, pois o custo seria em grande parte absorvido pelos Estados doadores mediante o aumento da ajuda externa (Frankel 2005; Blustein 2005). Note-se que, em momento algum, houve desacordo entre as potências quanto à exigência de que, para ser elegível ao perdão da dívida, os países pobres tivessem de implementar uma série de condicionalidades econômicas e institucionais estabelecidas pelas IFIs. O desacordo era sobre o instrumento para fazer cumprir as condicionalidades, e não sobre o princípio da condicionalidade.

O compromisso final, conhecido como Acordo de Gleneagles, aproximouse mais da proposta americana do que da britânica, seguindo o princípio de que o ônus recairia, sobretudo, sobre as IFIs, com a promessa dos doadores de, num futuro incerto, aumentar as contribuições para a AID. O Banco Mundial e doadores europeus argumentaram que a conversão de empréstimos em subvençôes e o cancelamento da dívida sem a compensação por parte dos doadores reduziriam significativamente a capacidade de financiamento da AID. As consequências de longo prazo do Acordo sobre o financiamento dos BMDs eram incertas no final do governo Bush (Babb 2009, 202).

\section{Conclusões}

O fato de uma comissão do Congresso americano ter produzido, ainda que não consensualmente, propostas como as contidas no Relatório Meltzer, seria impensável sem a confluência específica de determinadas pressões internacionais e domésticas. No âmbito internacional, a irrupção de crises financeiras sucessivas, que expuseram o grau de instabilidade da economia internacional e as contradiçóes da liberalização. No âmbito doméstico, o acirramento da disputa política entre o governo Clinton e a maioria republicana no Congresso. 
No geral, a resposta do Tesouro ao Relatório Meltzer não fez mais do que reafirmar as linhas gerais da liberalização econômica. No tocante aos BMDs, as suas propostas enfatizaram a promoção das reformas institucionais, o reforço das condicionalidades e a manutenção das IFIs como "bombeiras" da globalização financeira. Nenhuma reforma relevante foi cogitada. Sem surpresa, o repasse de funçōes do Banco Mundial para os bancos regionais - mais suscetíveis à influência dos Estados da periferia do que o Banco Mundial - foi rejeitado. Afinal, como fez questão de frisar Allan Meltzer, "os Estados Unidos têm um controle mais direto sobre o Banco Mundial”, razão pela qual "o Tesouro dos EUA não deseja ver um deslocamento de responsabilidade e poder" para tais Estados (Meltzer et al. 2000, 7). No tocante ao FMI, igualmente nenhuma mudança relevante foi considerada.

Com o governo Bush, algumas ideias do Relatório Meltzer para reformar as IFIs se traduziram na política americana. As principais delas foram a transformação de empréstimos dos BMDs em subvençôes e o cancelamento total da dívida multilateral dos países pobres altamente endividados que cumprissem um conjunto de condicionalidades. Retomando o discurso tradicional da direita republicana acerca do ônus financeiro dos organismos multilaterais para o Tesouro dos EUA, a defesa do cancelamento da dívida feita pelo governo Bush se baseava na ideia de que o perdão custaria muito pouco ou nada para o contribuinte americano, pois seria assumido na sua maior parte pelas IFIs. Os desdobramentos financeiros de tais iniciativas compõem o rol de questões em pauta nas negociações pela reforma do Banco Mundial e do FMI.

De todo modo, a concentração, a mutação e a geografia cambiante da crise econômica deflagrada em 2008 nos países mais ricos, e o subsequente fortalecimento financeiro das IFIs amparado pelos seus acionistas mais poderosos, constituem um cenário bastante distinto dos anos 1990, quando crises financeiras eclodiram em países emergentes na Ásia, na África e na América Latina. Frente a temas como o socorro financeiro a países europeus pelo FMI, a questão do cancelamento da dívida multilateral dos países pobres altamente endividados tende a ser posta de lado.

\section{Referências bibliográficas}

BANCO MUNDIAL. Relatório sobre o Desenvolvimento Mundial - O Estado num mundo em transformação. Washington DC: Oxford University Press, 1997.

BANCO MUNDIAL. Relatório sobre o Desenvolvimento Mundial - Do plano ao mercado. Washington DC: Oxford University Press, 1996.

BANCO MUNDIAL. ¿Qué significa para el Banco Mundial la reforma del Estado? Washington DC: The Word Bank, 1996a.

BANCO MUNDIAL. Informe sobre el Desarrollo Mundial - La tarea acuciante del desarrollo. Washington DC: Oxford University Press, 1991. 
BABB, Sarah. Behind the Development Banks: Washington Politics, World Poverty, and the Wealthy of Nations. Chicago and London: The University of Chicago Press, 2009, 313 p.

BANDOW, Doug e VÁSQUEZ, Ian (eds.). Perpetuating Poverty: the World Bank, the IMF, and the Developing World. Washington DC: Cato Institute, 1994, 362 p.

BLUSTEIN, Paul. Debt Cut is se for Poorest Nations. Washington Post, June 12, 2005.

BRZEZINSKI, Zbigniew. El gran tablero mundial. La supremacia estadunidense y sus imperativos geoestratégicos. Barcelona: Paidós, 1998, 217 p.

BURKI, Shahid Javed e PERRY, Guillermo. Más allá del Consenso de Washington: la hora de la reforma institucional. Washington DC: Banco Mundial, 1998.

COOPER, Robert. The Breaking of Nations: Order and Chaos in the Twenty-First Century. New York: Grove Press, 2003, 180 p.

DANAHER, Kevin (ed.). 50 Years is Enough: the Case Against the World Bank and the International Monetary Fund. Boston: South End Press, 1994, 207 p.

DEZALAY, Yves e GARTH, Bryant. La internacionalización de las luchas por el poder: la competencia entre abogados y economistas por transformar los Estados latinoamericanos. México DF: Instituto de Investigaciones Jurídicas/Universidad Nacional Autónoma de México, 2005, 371 p.

EBERSTADT, Nicholas e LEWIS, Clifford M. Privatizing the World Bank, The National Interest, no 40, summer, 1995, p. 14-19.

FRANKEL, Glenn. G-7 Backs Debt Plan for Poor Countries. Washington Post, February 6, 2005.

FUKUYAMA, Francis. Construção de Estados: governo e organização no século XXI. Rio de Janeiro: Rocco, 2005, 168 p.

LANCASTER, Carol. Foreign Aid: Diplomacy, Development, Domestic Politics. Chicago and London: The University of Chicago Press, 2007, 284 p.

MALLABY, Sebastian. The World's Banker: a Story of Failed States, Financial Crises, and the Wealth and Poverty of Nations. New York: Penguin Books, 2004, 488 p.

MELTZER, Allan et al. Informe de la Comisión de Asesoramiento para las Instituciones Financieras Internacionales. Washington DC, março, 2000 (traduzido pela Fundação Heritage).

PEREIRA, João Márcio Mendes. O Banco Mundial como ator político, intelectual e financeiro (1944-2008). Rio de Janeiro: Civilização Brasileira, 2010, 504 p.

U.S. DEPARTMENT OF TREASURY. Response to the Report of the International Financial Institution Advisory Commission. Washington DC, June 8, 2000.

Recebido em 22 de fevereiro de 2011 Aprovado em 15 de junho de 2011 


\section{Resumo}

O artigo discute as propostas do Relatório Meltzer para a reforma do Banco Mundial e do Fundo Monetário Internacional. Esse relatório resultou do trabalho realizado entre 1998 e 2000 por uma comissão do Congresso americano. Discute também a resposta do Tesouro americano àquelas propostas e mostra como algumas delas foram implementadas seletivamente pelo governo de George W. Bush.

Palavras-chave: Banco Mundial; FMl; governo George W. Bush; relatório Meltzer; Tesouro dos EUA.

\section{Abstract}

The article discusses the propositions of the Meltzer Report for the reform of the World Bank and the International Monetary Fund. This report came from the work conducted between 1998 and 2000 by a Commission from the North American Congress. Afterwards, it discusses the reply from the American Treasury to those propositions and shows how some of them were selectively implemented by the George W. Bush administration.

Keywords: World Bank; IMF; George W. Bush administration; Meltzer report; U.S. Treasury. 